\title{
Woody Plant Encroachment and the Sustainability of Priority Conservation Areas
}

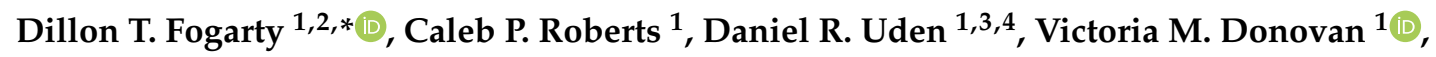 \\ Craig R. Allen ${ }^{3,4}$, David E. Naugle ${ }^{5}$, Matthew O. Jones ${ }^{5,6}{ }^{\circledR}$, Brady W. Allred ${ }^{5,6}$ and \\ Dirac Twidwell 1,3 (1) \\ 1 Department of Agronomy \& Horticulture, University of Nebraska, Keim Hall, Lincoln, NE 66583-0915, USA; \\ caleb.powell.roberts@gmail.com (C.P.R.); duden2@unl.edu (D.R.U.); vdonovan2@unl.edu (V.M.D.); \\ dirac.twidwell@unl.edu (D.T.) \\ 2 Nebraska Cooperative Fish and Wildlife Research Unit, School of Natural Resources, University of Nebraska, \\ Hardin Hall, Lincoln, NE 68583-0961, USA \\ 3 Center for Resilience in Agricultural Working Landscapes, University of Nebraska, Keim Hall, \\ Lincoln, NE 66583-0915, USA; callen3@unl.edu \\ 4 School of Natural Resources, University of Nebraska, Hardin Hall, Lincoln, NE 68583-0961, USA \\ 5 W.A. Franke College of Forestry and Conservation, University of Montana, 32 Campus Drive, \\ Missoula, MT 59812,USA; david.naugle@umontana.edu (D.E.N.); matt.jones@mso.umt.edu (M.O.J.); \\ Brady.allred@umontana.edu (B.W.A.) \\ 6 Numerical Terradynamic Simulation Group, University of Montana, 32 Campus Drive, \\ Missoula, MT 59812, USA \\ * Correspondence: dillon.fogarty@huskers.unl.edu
}

Received: 19 September 2020; Accepted: 7 October 2020; Published: 9 October 2020

check for updates

\begin{abstract}
Woody encroachment is a global driver of grassland loss and management to counteract encroachment represents one of the most expensive conservation practices implemented in grasslands. Yet, outcomes of these practices are often unknown at large scales and this constrains practitioner's ability to advance conservation. Here, we use new monitoring data to evaluate outcomes of grassland conservation on woody encroachment for Nebraska's State Wildlife Action Plan, a statewide effort that targets management in Biologically Unique Landscapes (BULs) to conserve the state's natural communities. We tracked woody cover trajectories for BULs and compared BUL trajectories with those in non-priority landscapes (non-BULs) to evaluate statewide and BUL-scale conservation outcomes more than a decade after BUL establishment. Statewide, woody cover increased by 256,653 ha $(2.3 \%)$ from 2000-2017. Most BULs (71\%) experienced unsustainable trends of grassland loss to woody encroachment; however, management appeared to significantly reduce BUL encroachment rates compared to non-BULs. Most BULs with early signs of encroachment lacked control strategies, while only one BUL with moderate levels of encroachment (Loess Canyons) showed evidence of a management-driven stabilization of encroachment. These results identify strategic opportunities for proactive management in grassland conservation and demonstrate how new monitoring technology can support large-scale adaptive management pursuits.
\end{abstract}

Keywords: adaptive management; brush management; conservation outcomes; Eastern redcedar; ecosystem monitoring; large-scale conservation; sustainability; tree invasion; woody plant encroachment; working lands

\section{Introduction}

Woody plant encroachment is a global driver of grassland loss and represents a primary threat to grassland ecosystem services [1-5]. A combination of anthropogenic changes to fire and herbivory 
regimes, climate, and woody plant distributions have led to rapid expansion of woody plants in grass-dominated ecosystems at the expense of grassland-dependent species [6-8]. In North America, grassland birds have experienced the largest population decline across breeding biomes, with a loss of $\sim 700$ million breeding birds since 1970 [9]. Halting and reversing woody encroachment is therefore a central goal in grassland conservation $[5,10,11]$. The risks of failing to halt woody plant encroachment and conserve remaining grasslands include a loss of biodiversity [3,12], reduced freshwater supply and quality [2,13], increased wildfire hazard [14,15], reduced food production [1], and endangerment of livelihoods and human well-being $[5,16]$. These risks are well known and justify major conservation expenditures in excess of tens of millions of dollars per year to clear woody plants and stabilize and restore grassland ecosystem services [17-19]. However, more land area continues to be lost to woody plant encroachment in grassy biomes [20-23]. Brush management practices have consequently come under global scrutiny for their unproven ability to halt or reverse trends of woody plant encroachment at large scales $[10,19,24,25]$.

Despite rising conservation expenditures and the identification of large-scale priority areas [26-28], outcomes are often unknown at targeted scales and constrain practitioner's ability to scale-up efforts to biologically meaningful scales. However, new geospatial data products with broad geographic coverage and fine spatial resolution have bridged gaps between vegetation monitoring and large-scale conservation targets $[20,29,30]$ and made it possible to track annual changes in vegetation at scales relevant to large-scale adaptive management pursuits [21]. Specifically, opportunities exist to learn from decades of efforts to scale up grassland conservation, identify areas that serve as models of conservation success, and better inform where adaptive measures are needed. This information is critically needed; to date, there are no examples known to have halted or reversed the progression of woody plant encroachment at an ecoregion or larger scale.

Heightened concerns regarding wildlife and habitat loss have helped spur the development of regional and statewide blueprints to scale-up grassland conservation efforts in priority areas [28,30,31]. The State Wildlife Action Plan for Nebraska provided an early model for the establishment of large-scale priority areas (termed Biologically Unique Landscapes in the State Wildlife Action Plan; established in 2005). These Biologically Unique Landscapes (BULs) provide a network of sites for targeted conservation investments and represent a wide range of approaches for conserving at-risk species and habitats vulnerable to woody plant encroachment [27]. This study leverages more than a decade of efforts to scale-up conservation actions in these priority areas as a case study to examine the effectiveness of brush management practices for controlling woody plant encroachment and sustaining grasslands.

In support of ongoing conservation efforts, we assess the sustainability of grasslands in BULs in relation to woody plant encroachment. This assessment comes at a critical time; Nebraska is considered to be on the front lines of a woody transition front sweeping northward in the Great Plains biome [32]. We use new rangeland monitoring technologies (Rangeland Analysis Platform; [29]) to track woody plant cover trajectories from 2000 to 2017 and apply a conceptual framework for comparing observed trajectories to desired sustainability outcomes. Specifically, we compare trends in woody plant encroachment between BUL and non-BUL grasslands, quantify woody cover trajectories for all BULs, and assess their sustainability more than a decade after initial prioritization. This study showcases new opportunities to leverage advanced spatial technologies to more rapidly execute adaptive management and spatially-target conservation to achieve large-scale goals.

\section{Materials and Methods}

\subsection{The Nebraska Natural Legacy Project}

The Nebraska Natural Legacy Project is Nebraska's State Wildlife Action Plan that aims to (1) reverse the decline of at-risk species, (2) recover currently listed species, (3) keep common species common, and (4) conserve natural communities [27]. The Project was initiated in 2005 as a blueprint for conserving grasslands and grassland-dependent species (among other natural communities and species) 
in light of large-scale stressors [27]. Priorities are organized around ecoregions and BULs embedded within those regions. Ecoregions include the tallgrass, mixedgrass, Sandhills, and shortgrass prairie regions, and largely reflect delineations developed by Chapman and others in 2001 [33] (also see [27]). The BULs are priority areas for conservation that were identified as critical to the conservation of the state's biodiversity due to their relatively intact natural communities known to support at-risk species. In this study, we used all BULs with grassland communities identified as a conservation priority (21 of 39; Table 1). Together these BULs represent 39\% of Nebraska's rangeland area. Non-BUL grasslands in this study refer to areas in Nebraska that are not included in the state's 39 BULs and represent $54 \%$ of the state's rangeland area (Table 1).

Table 1. Description of Biologically Unique Landscapes (BULs) and woody cover trends in rangelands from 2000 to 2017, Nebraska, USA.

\begin{tabular}{|c|c|c|c|c|c|}
\hline BUL & Conservation Priorities $^{1}$ & Area (ha) & $\begin{array}{l}\text { Rangeland } \\
\text { Area (ha) }\end{array}$ & $\begin{array}{l}\text { Woody } \\
\text { Cover } \\
\text { Change (ha) }\end{array}$ & $\begin{array}{l}\text { Mann-Kendall } \\
\text { Trend Test } \\
(P \text { Value })\end{array}$ \\
\hline $\begin{array}{l}\text { Elkhorn } \\
\text { Confluence }\end{array}$ & Bur oak forest and woodland; tallgrass prairie & 38,122 & 19,111 & 1604 & $<0.001$ \\
\hline Ponca Bluffs & $\begin{array}{l}\text { Bur oak-basswood-ironwood forest; bur oak forest and woodland; } \\
\text { tallgrass prairie northern loess/shale bluff prairie; eastern sandstone } \\
\text { bluff and cliff }\end{array}$ & 41,721 & 22,479 & 1887 & $<0.001$ \\
\hline $\begin{array}{l}\text { Rainwater } \\
\text { Basin }\end{array}$ & $\begin{array}{l}\text { Cattail shallow marsh; eastern bulrush deep marsh; wheatgrass playa } \\
\text { grassland; playa wetland; cattail shallow marsh }\end{array}$ & $1,590,738$ & 21,4701 & 12,424 & $<0.001$ \\
\hline $\begin{array}{l}\text { Sandstone } \\
\text { Prairies }\end{array}$ & $\begin{array}{l}\text { Sandstone bur oak woodland; freshwater seep; prairie fen; tallgrass } \\
\text { prairie; Dakota sandstone tallgrass prairie; southern sand/gravel } \\
\text { prairie; eastern sandstone bluff and cliff }\end{array}$ & 107,208 & 54,172 & 2218 & $<0.001$ \\
\hline $\begin{array}{l}\text { Southeast } \\
\text { Prairies }\end{array}$ & $\begin{array}{l}\text { Bur oak forest and woodland; eastern cordgrass wet prairie; } \\
\text { tallgrass prairie }\end{array}$ & 234,346 & 134,955 & 5196 & 0.006 \\
\hline $\begin{array}{l}\text { Willow Creek } \\
\text { Prairies }\end{array}$ & $\begin{array}{l}\text { Eastern cordgrass wet prairie; } \\
\text { Eastern sedge wet meadow; tallgrass prairie; eastern sand prairie } \\
\text { Bur oak forest and woodland; freshwater seep; tallgrass prairie; }\end{array}$ & 23,034 & 12,038 & 685 & 0.002 \\
\hline Verdigris-Bazile & $\begin{array}{c}\text { northern loess/shale bluff prairie; Great Plains gravel-cobble prairie; } \\
\text { northern chalk bluff and cliff }\end{array}$ & 283,950 & 199,422 & 13,901 & $<0.001$ \\
\hline $\begin{array}{l}\text { Cherry County } \\
\text { Wetlands }\end{array}$ & $\begin{array}{l}\text { Sandhills fen; Sandhills wet meadow; spikerush vernal pool; cattail } \\
\text { shallow marsh; Sandhills hardstem bulrush marsh; reed marsh; } \\
\text { northern pondweed aquatic wetland; water-lily aquatic wetland; } \\
\text { Sandhills mesic tallgrass prairie }\end{array}$ & 709,202 & 650,338 & 4216 & 0.001 \\
\hline $\begin{array}{l}\text { Dismal river } \\
\text { headwaters }\end{array}$ & $\begin{array}{l}\text { Sandhills fen; Sandhills wet meadow; spikerush vernal pool; cattail } \\
\text { shallow marsh; reed marsh; northern pondweed aquatic wetland; } \\
\text { water-lily aquatic wetland; }\end{array}$ & 268,448 & 253,480 & 1622 & $<0.001$ \\
\hline $\begin{array}{l}\text { Elkhorn River } \\
\text { Headwaters }\end{array}$ & $\begin{array}{l}\text { Cottonwood-diamond willow woodland; sandbar willow shrubland; } \\
\text { Sandhills fen; Sandhills wet meadow; cattail shallow marsh; Sandhills } \\
\text { hardstem bulrush marsh; reed marsh; northern pondweed aquatic } \\
\text { wetland; eastern sand prairie; Sandhills mesic tallgrass prairie }\end{array}$ & 517,863 & 449,123 & 12,102 & 0.001 \\
\hline $\begin{array}{l}\text { Sandhills } \\
\text { Alkaline Lakes }\end{array}$ & $\begin{array}{l}\text { Western alkaline meadow; western alkaline marsh; saline/alkaline } \\
\text { aquatic wetland; Sandhills dune prairie }\end{array}$ & 357,553 & 330,644 & 2842 & $<0.001$ \\
\hline $\begin{array}{c}\text { Central Loess } \\
\text { Hills }\end{array}$ & Playa wetland; loess mixedgrass prairie & 567,610 & 435,480 & 11,986 & 0.001 \\
\hline Keya Paha & $\begin{array}{c}\text { Bur oak woodland; northern cordgrass wet prairie; eastern sand } \\
\text { prairie; Great Plains gravel-cobble prairie }\end{array}$ & 146,599 & 125,938 & 2311 & $<0.001$ \\
\hline Loess Canyons & Loess mixedgrass prairie & 136,767 & 118,070 & 8295 & $<0.001$ \\
\hline $\begin{array}{l}\text { Middle } \\
\text { Niobrara }\end{array}$ & $\begin{array}{c}\text { Bur oak woodland; paper birch springbranch canyon forest; } \\
\text { basswood-ironwood springbranch canyon forest; ponderosa pine } \\
\text { open woodland and savanna; freshwater seep; cattail shallow marsh; } \\
\text { Sandhills dune prairie; Great Plains gravel-cobble prairie; perennial } \\
\text { sandbar; sandbar/mudflat }\end{array}$ & 137,567 & 117,239 & 2312 & 0.004 \\
\hline $\begin{array}{l}\text { Kimball } \\
\text { Grasslands }\end{array}$ & Threadleaf sedge western mixedgrass prairie; rock outcrop & 109,303 & 67,139 & 241 & 0.289 \\
\hline $\begin{array}{l}\text { Oglala } \\
\text { Grasslands }\end{array}$ & $\begin{array}{l}\text { Western sedge wet meadow; threadleaf sedge western mixedgrass } \\
\text { prairie; northwestern mixedgrass prairie; western floodplain terrace } \\
\text { grassland; silver sagebrush shrub prairie; greasewood shrub prairie; } \\
\text { rock outcrop; badlands }\end{array}$ & 289,550 & 25,3764 & 132 & 0.198 \\
\hline $\begin{array}{l}\text { Panhandle } \\
\text { Prairies }\end{array}$ & $\begin{array}{l}\text { Western sedge wet meadow; western sand prairie; threadleaf sedge } \\
\text { western mixedgrass prairie; wheatgrass western mixedgrass prairie; } \\
\text { rock outcrop }\end{array}$ & 476,755 & 431,975 & 1157 & 0.198 \\
\hline Pine Ridge & $\begin{array}{l}\text { Green ash-elm-hackberry canyon bottom woodland; ponderosa pine } \\
\text { forest, open woodland, and savanna; Pine-juniper scarp woodland; } \\
\text { freshwater seep; western sedge wet meadow; western sand prairie; } \\
\text { threadleaf sedge western mixedgrass prairie; northern chalk bluff and } \\
\text { cliff; western sandstone cliff; rock outcrop }\end{array}$ & 213,151 & 138,568 & 260 & 0.363 \\
\hline $\begin{array}{l}\text { Sandsage } \\
\text { Prairie }\end{array}$ & Loess mixedgrass prairie, Sandsage prairie & 418,705 & 275,892 & 1302 & 0.001 \\
\hline Wildcat Hills & $\begin{array}{l}\text { Ponderosa pine forest, open woodland, and savanna; pine-juniper } \\
\text { scarp woodland; mountain mahogany shrubland; freshwater seep; } \\
\text { sandsage prairie; western sand prairie; threadleaf sedge western } \\
\text { mixedgrass prairie; wheatgrass western mixedgrass prairie; western } \\
\text { sandstone cliff; rock outcrop; badlands }\end{array}$ & 169,372 & 138,154 & 1131 & 0.001 \\
\hline
\end{tabular}


Table 1. Cont.

\begin{tabular}{cccccc}
\hline BUL & Conservation Priorities ${ }^{1}$ & Area (ha) & $\begin{array}{c}\text { Rangeland } \\
\text { Area (ha) }\end{array}$ & $\begin{array}{c}\text { Woody Cover } \\
\text { Change (ha) }\end{array}$ & $\begin{array}{c}\text { Mann-Kendall } \\
\text { Trend Test }(\boldsymbol{P} \text { Value) }\end{array}$ \\
\hline All BULs & - & $6,837,564$ & $4,439,883$ & 94,400 & $<0$ \\
Non-BULs & - & $21,039,504$ & $6,176,883$ & 142,409 & $<0.001$ \\
Nebraska & - & $35,788,741$ & $11,424,273$ & 256,653 & $<0.001$ \\
\hline
\end{tabular}

${ }^{1}$ Listed conservation priorities represent terrestrial communities that are prioritized for conservation in each BUL.

Nebraska is a grass-dominated state in the central portion of the Great Plains temperate grassland biome (Figure 1) and hosts some of North America's most intact grasslands. Differences in grassland plant communities are largely driven by a longitudinal precipitation gradient [34]. Mean annual precipitation is greatest in the east $(\max 876 \mathrm{~mm}$ ) in the tallgrass prairie and declines westward into the mixedgrass and shortgrass prairies ( $\min 385 \mathrm{~mm}$; [35]). The Sandhills ecoregion intersects the above ecoregions and is differentiated by its unique vegetated sand dune topography; mean annual precipitation ranges from 457 to $810 \mathrm{~mm}$ [35]. Elevation generally increases from east to west (255-1653 m; US Geological Survey). Major land uses include cow-calf livestock production on perennial rangelands throughout the state, and row crop production in eastern Nebraska and in locations that support the use of center-pivot irrigation.

Trees were historically maintained as rare species in Nebraska by fire, the primary natural obstacle to trees in the Great Plains [36,37]. Fire suppression and restriction, and tree planting has led to woody plant encroachment, originating from cultivated and historic sources of propagules, and expanding into previously treeless grasslands $[5,38,39]$. Rates of woody plant encroachment vary across the state based on climate, fire and herbivory regimes, woody plant species, and interactive effects among these factors [40]. The Nebraska Natural Legacy Project represents the state's most comprehensive plan for confronting woody plant encroachment and identifies Eastern redcedar (Juniperus virginiana) encroachment, as a biodiversity stressor in all ecoregions [27]. Encroachment by other native and non-native woody species such as Osage orange (Maclura pomifera), Russian olive (Elaeagnus angustifolia), Siberian elm (Ulmus pumila), and honey locust (Gleditsia triacanthos) are identified as biodiversity stressors in a subset of BULs [27].

Most BUL-based management occurs within Nebraska's privately-owned (97\%) land base. Management actions are implemented by private land managers or through voluntary conservation incentive programs. Incentive programs leverage technical and financial assistance from natural resource agencies to build partnerships with landowners and aim to benefit biodiversity and help sustain the profitability of working lands. Mechanical tree removal projects applied at small scales (15-20 ha) represent the most incentivized practice on private lands and accounts for the vast majority of financial assistance, with fewer funds allocated towards prescribed fire and herbicide treatments [25,41,42]. Other forms of agency assistance include technical guidance and access to resources for prescribed burning.

\subsection{Data and Analysis}

We assessed woody cover change using percent tree cover data taken from the Rangeland Analysis Platform [29]. Tree cover data spanned years 2000-2017 with an annual temporal resolution, 30-m spatial resolution, and mean absolute error for percent tree cover of 4.7 [29]. The study area includes all rangelands in Nebraska based on Reeves and Mitchell's 2011 classification of US rangelands [43]. This includes rangeland pixels classified as afforested. Afforested rangelands are defined as former rangelands that in 2001 had sufficient tree cover $(\geq 25 \%)$ to be classified as forest by common land classification systems (e.g., National Land Cover Database) [43]. We combined rangeland and afforested pixels for all analyses, given that afforested rangelands accounted for $<1 \%$ of the total area evaluated statewide and a sensitivity analysis of our results showed similar changes in woody cover when separating rangelands and afforested rangelands (see Figure S1-S2 and Table S1). Wetlands occurring within rangeland areas were excluded from this analysis, based on delineations used in the National 
Wetlands Inventory [43]. In total, this resulted in an analysis that tracked annual changes in woody cover for a total of 170,299,889 30-m pixels across 15,326,990 ha.

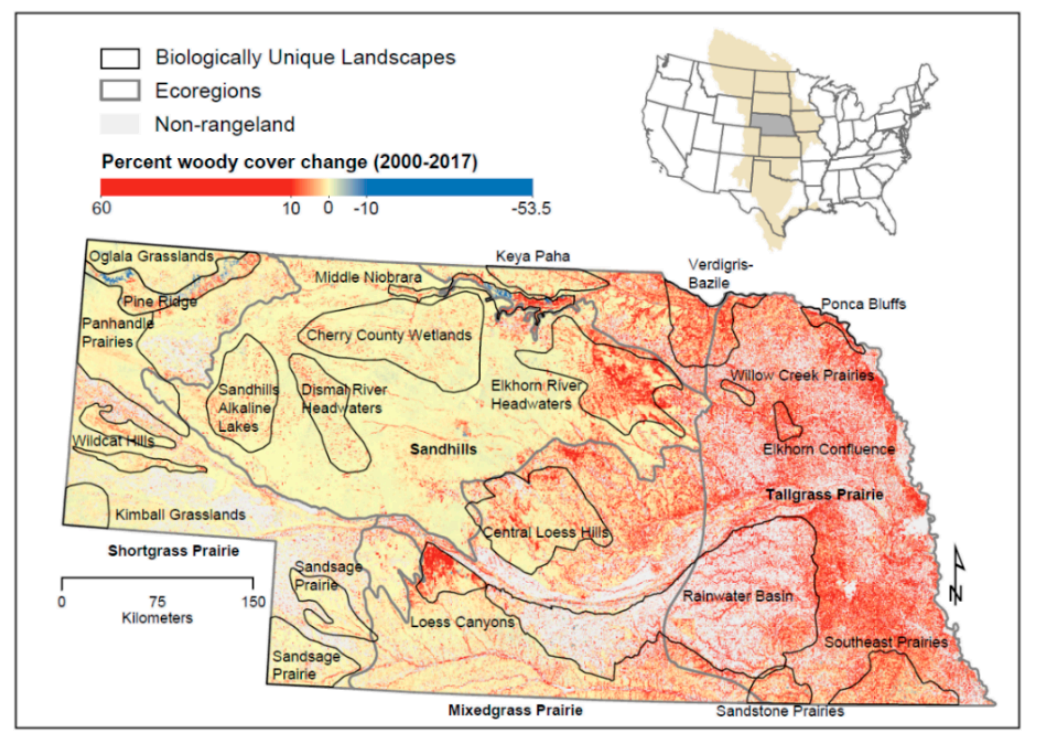

Figure 1. Percent woody cover change in Nebraska's Biologically Unique Landscapes (BULs) from 2000-2017. Grey areas represent non-rangeland pixels based on Reeves and Mitchell's 2011 classification of US rangelands [43]. Inset map (top right) depicts the coterminous US and the Great Plains temperate grassland biome.

We used generalized additive models ('gam' function in package mgcv [44]) to track woody plant trajectories (modeled as percent cover and woody canopy area) from 2000 to 2017 at statewide, BUL, and non-BUL extents to examine grassland conservation outcomes. For all generalized additive models, we set percent cover as the response variable and time (in years, starting in 2000) as the smoothed predictor variable. We then used the Mann-Kendall trend test [45] to test for significant increasing or decreasing trends in woody cover. The Mann-Kendall trend test is a nonparametric method that provides a robust estimate of whether time series data have significant increasing or decreasing trends [46]. We conducted all statistical analyses using $R$ version 3.5.1 [47].

We assessed grassland conservation outcomes based on the stage of woody plant encroachment and whether woody cover trajectories were consistent with desired conservation outcomes (e.g., stabilization of woody encroachment trend) (Table 2). The stage of woody plant encroachment and conservation outcomes were based on the density-impact model for biological invasions [25,48]. Woody plant encroachment stage (none, early, mid, and late) was determined based on the level and trajectory of woody cover (none: low and stable woody cover; early: low but increasing woody cover; mid: moderate [ $>2 \%$ ] and increasing woody cover; late: high and stable woody cover) (Table 2 ). In evaluating conservation outcomes, we also considered whether BULs had strategies outlined to control woody plants in the Nebraska Natural Legacy Project [27]. BULs were considered to have a control strategy if they listed woody plant encroachment as a biodiversity stressor and outlined strategies to confront it (e.g., increased use of tree clearing programs to reduce Eastern redcedar). 
Table 2. Woody plant encroachment (WPE) stages, desired conservation outcomes and associated science-based conservation strategies compared to observed woody encroachment stage and trajectory from 2000 to 2017 for each grassland Biologically Unique Landscape (BUL) in Nebraska, USA.

\begin{tabular}{|c|c|c|c|c|c|c|c|}
\hline \multirow{2}{*}{ WPE Stage } & \multirow{2}{*}{$\begin{array}{l}\text { Current (-) and } \\
\text { Desired (- - ) WPE } \\
\text { Trajectory }\end{array}$} & \multirow{2}{*}{$\begin{array}{l}\text { Strategy for Desired } \\
\text { Conservation } \\
\text { Outcomes }\end{array}$} & \multicolumn{4}{|c|}{ BUL WPE Stage } & \multirow{2}{*}{$\begin{array}{l}\text { BULs with Desired } \\
\text { Conservation Trajectory }\end{array}$} \\
\hline & & & $\begin{array}{c}\mathrm{TG}^{1} \\
(\mathrm{n}=7)\end{array}$ & $\begin{array}{l}\mathrm{MG}^{1} \\
(\mathrm{n}=4)\end{array}$ & $\begin{array}{c}\mathrm{SH}^{1} \\
(\mathrm{n}=4)\end{array}$ & $\begin{array}{c}\mathrm{SG}^{1} \\
(\mathrm{n}=6)\end{array}$ & \\
\hline None & 章 & Prevention & - & - & - & $\begin{array}{c}\text { Kimball Grasslands *, } \\
\text { Oglala Grasslands *, } \\
\text { Panhandle Prairies *, } \\
\text { Pine Ridge }\end{array}$ & $\begin{array}{l}\text { Kimball Grasslands, } \\
\text { Oglala Grasslands, } \\
\text { Panhandle Prairies, } \\
\text { Pine Ridge }\end{array}$ \\
\hline Early & Time & Early Intervention & - & - & $\begin{array}{l}\text { Cherry County Wetlands*, } \\
\text { Dismal River Headwaters, } \\
\text { Sandhills Alkaline Lakes* }\end{array}$ & $\begin{array}{l}\text { Sandsage Prairie*, } \\
\text { Wildcat Hills }\end{array}$ & None \\
\hline Mid & है & $\begin{array}{l}\text { Restoration or } \\
\text { Stabilization }\end{array}$ & $\begin{array}{c}\text { Elkhorn Confluence, Ponca Bluffs, } \\
\text { Rainwater Basin*, } \\
\text { Sandstone Prairies, } \\
\text { Southeast Prairies, } \\
\text { Willow Creek Prairies *, } \\
\text { Verdigris-Bazile }\end{array}$ & $\begin{array}{l}\text { Central Loess Hills, } \\
\text { Keya Paha, } \\
\text { Loess Canyons, } \\
\text { Middle Niobrara }\end{array}$ & Elkhorn River Headwaters & - & $\begin{array}{c}\text { Loess Canyons (stabilization), } \\
\text { Middle Niobrara } \\
\text { (stabilization) }\end{array}$ \\
\hline Late & ơ & $\begin{array}{l}\text { Rehabilitation or } \\
\text { Transformation }\end{array}$ & None & None & None & None & $\mathrm{N} / \mathrm{A}^{1}$ \\
\hline & Time & & & & & & \\
\hline
\end{tabular}

\footnotetext{
${ }^{1}$ Abbreviations: $\mathrm{TG}=$ tallgrass prairie; $\mathrm{MG}=$ mixedgrass prairie; $\mathrm{SH}=$ Sandhills; $\mathrm{SG}=$ shortgrass prairie; N/A = not applicable. * Signifies BULs that do not have a woody plant control
} strategy identified in the Nebraska Natural Legacy Project. 


\section{Results}

\subsection{Comparison of Woody Plant Encroachment in BULs and Non-BULs}

Woody cover area was similar in BUL and non-BUL landscapes before Nebraska's State Wildlife Action Plan, as known as the Nebraska Natural Legacy Project, was enacted (ca. 2005; Figure 2). Woody plants expanded in both BUL and non-BUL landscapes regardless of project goals (Figure 2). Non-overlapping 95\% confidence intervals from years 2008-2017 indicated that woody plant encroachment occurred more slowly in BULs (5553 ha year ${ }^{-1}$ ) than in non-BULs (8377 ha year ${ }^{-1}$ ). Differential rates of woody plant encroachment resulted in 46,189 fewer hectares of woody plant cover in BULs compared to non-BULs in 2017.

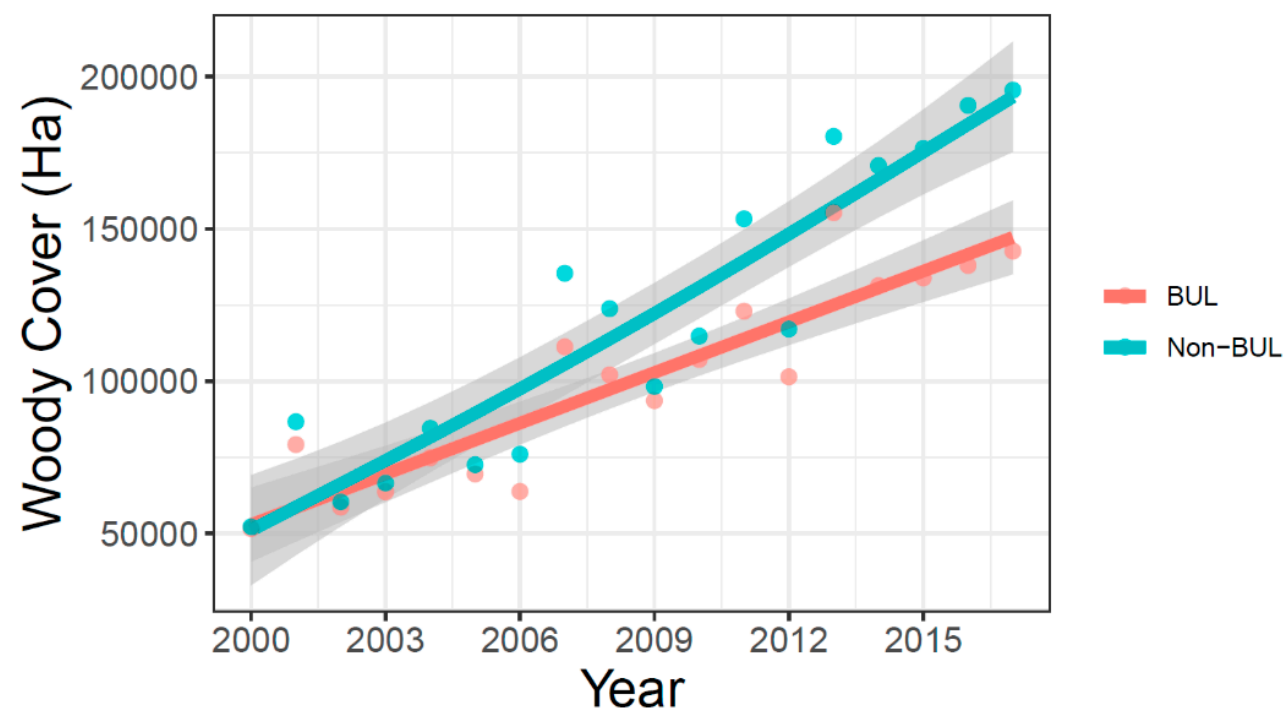

Figure 2. Change in area of woody cover in rangelands for grassland BULs compared to non-BUL grasslands, 2000-2017 in Nebraska, USA.

\subsection{Trajectory of Woody Plant Encroachment within BULs}

Assessment of woody cover change from 2000 to 2017 showed an overarching trend of woody plant encroachment across the state's BULs. Overall, woody cover increased from $1.0 \%( \pm 0.13 \mathrm{SE})$ to $3.3 \%$ ( $\pm 0.13 \mathrm{SE})$ statewide in Nebraska from 2000-2017, respectively, representing 256,653 ha of grassland area lost to woody plant encroachment over that time frame (Figure 1; Table 1). Most BULs followed the statewide trend of increasing woody cover. In general, initial small amounts of woody cover in BULs trended higher over time (Table 1; Figure 3). Significant positive trends in woody cover were observed in 17 of 21 BULs, including 100\% of BULs within tallgrass, mixedgrass, and Sandhills prairie ecoregions (Table 1; Figure 3; see Table S2 for generalized additive model outputs). Only four BULs, located in the more arid shortgrass prairie ecoregion, did not exhibit upward trends in woody cover from 2000 to 2017 (Table 1; Figure 3). Woody cover remained relatively low and stable through time in these four BULs (Figure 3).

BULs conformed to one of four woody cover trajectories associated with the stage of woody plant encroachment (Table 2). Among the 17 BULs with significant trends of woody plant encroachment, the majority of BULs experienced moderate levels of encroachment $(n=12)$, including all BULs from the tallgrass and mixedgrass prairie ecoregions, and one BUL from the eastern portion of the Sandhills (Elkhorn River Headwaters) (Table 2; Figure 3). Woody cover consistently increased for more than a decade in these BULs and was greater than 2\% in 2017 (Figure 3). A total of five BULs from the Sandhills and shortgrass prairie ecoregions were in the early stages of woody plant encroachment (Table 1). Woody cover was relatively low in these BULs $(\sim 1 \%)$, but significantly increased over time (Table 2). 

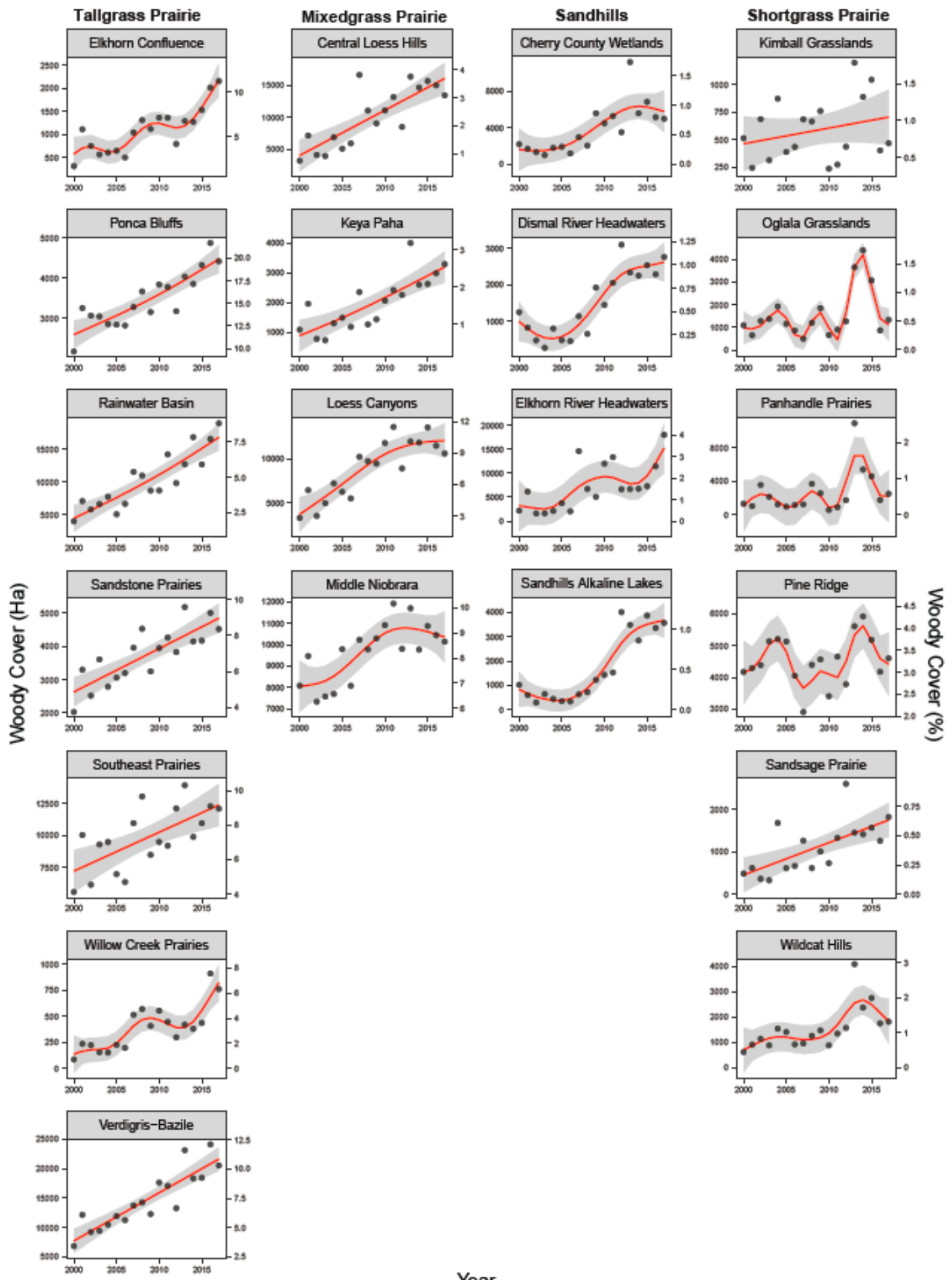

Figure 3. Woody cover trends in rangelands from generalized additive models for Biologically Unique Landscapes in Nebraska, USA (2000-2017). Left and right y-axis show woody cover in hectares and percent, respectively.

BULs in the early stages of woody plant encroachment were less likely than moderately degraded landscapes to have control strategies outlined in the Nebraska Natural Legacy Project (Table 2). Assignment of control strategies was inconsistent; increasing trends were similar in BULs with and without strategies despite low woody cover. Woody plant control strategies were deemed unnecessary in three of five BULs despite early and obvious signs of woody plant encroachment. 
Pine Ridge was the only BUL without a trend in woody plant encroachment that also had a strategy for controlling Eastern redcedar and reducing tree density in savanna, woodland, and forest communities. Despite moderate levels of woody plant encroachment, no control strategies were in place in the Rainwater Basin and Willow Creek Prairies, two BULs that have been mostly converted to row crop agriculture but still but contain a patchwork of prairies and corridors that are transitioning to woody plant dominance (Figures 1 and 3).

A small subset of BULs with significant trends of woody plant encroachment exhibited trajectories more consistent with desired restoration outcomes and grassland sustainability. In the mixedgrass prairie ecoregion, trends of increasing woody cover were stabilized in the Loess Canyons and Middle Niobrara BULs. In the Loess Canyons BUL, Eastern redcedar encroachment of loess mixedgrass prairie communities represents the primary biodiversity stressor related to increasing woody cover. From 2000 to 2011, woody cover increased in the Loess Canyons at an average annual rate of $0.56 \%\left(657\right.$ ha year $\left.{ }^{-1}\right)$, and then stabilized around 10\% from 2012 to 2017. The Middle Niobrara BUL is situated along a $122-\mathrm{km}$ reach of the Niobrara River where increasing densities of Eastern redcedar and ponderosa pine (Pinus ponderosa) in priority grassland, savanna, woodland, and forest communities represent the primary biodiversity stressor related to increasing woody cover. From 2000 to 2011, woody cover increased in the Middle Niobrara at an average annual rate of $0.21 \%$ (242 ha year ${ }^{-1}$ ) and then abruptly plateaued around $9 \%$ from 2012 to 2017. No BULs with moderate levels of woody plant encroachment reversed their trends of increasing woody cover. None of the five BULs in the early stages of woody plant encroachment showed evidence of restoring grassland dominance following relatively small increases in woody cover.

\section{Discussion}

Overall, our results show an unsustainable trajectory where grasslands were lost to encroaching woody plants despite efforts to halt and reverse these trends. Management actions to counteract woody plant encroachment tended to be outpaced by the rate of encroachment. These results are consistent with trends in grassy biomes throughout the world $[10,21,22]$ and highlight a growing need to learn from past efforts, rethink 'best practices', and identify new opportunities to scale-up grassland conservation. Current strategies to counteract woody plant encroachment adhere to a restoration paradigm of brush management where woody plant removal is prioritized over more proactive and preventative practices $[19,25]$. While this strategy appears to have slowed the rate of woody plant encroachment in priority areas, our results show that this approach is unlikely to sustain grasslands into the future unless more proactive and cost-effective strategies are adopted that can match the scale of degradation. Several BULs in the Sandhills and shortgrass prairie ecoregions did not have strategies in place for control of woody plants but displayed early signs of encroachment. These BULs represent cost-effective opportunities to move towards more proactive conservation strategies. Further, this study identified several BULs with outcomes that were consistent with conservation goals and provide a blueprint for scaling-up management in other regions.

In three BULs, increases in woody cover were counteracted by large areas that burned and experienced a reduction in woody cover, representing the only examples of woody cover trajectories that were consistent conservation goals (Figure 4). These BULs demonstrate a strong link between fire and grassland sustainability and echo decades of science that has tied fire-vegetation feedbacks to the long-term persistence of grassland biomes [36,37,49,50]. In comparison to brush management practices [11], fire is the only process that targets all stages of the woody plant encroachment process (ranging from seeds to mature trees) in a single application [51,52]. The Pine Ridge provides the only example of a BUL with stable woody cover that also listed woody encroachment as a biodiversity stressor. In this BUL, areas that experienced a decline in woody cover were associated with a series of large wildfires (Figure 4) [53] that likely played a major role in stabilizing woody plants in this landscape. Woody plant encroachment was stabilized in two landscapes that experienced moderate levels of encroachment. In the Middle Niobrara, wildfire perimeters from 2012 encompass areas that 
experienced a reduction in woody cover and correspond to an abrupt stabilization of woody cover trends following 2012 (Figure 4). In the Loess Canyons, reductions in woody cover and grassland stability were largely associated with prescribed fires that appear to have counteracted trends of woody plant encroachment and stabilized grassland resources [54]. These examples all feature large fires that substantially reduced woody cover and demonstrate the types of disturbance regimes that can be targeted with management to confront woody plant encroachment at large scales.

(a)
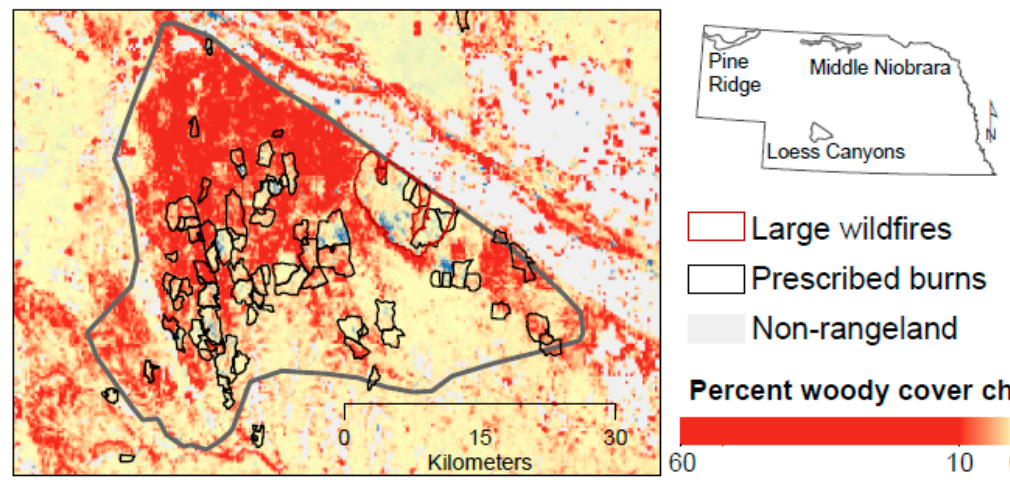

Percent woody cover change (2000-2017) $60 \quad 10 \quad 0 \quad-10 \quad-53$

(b)

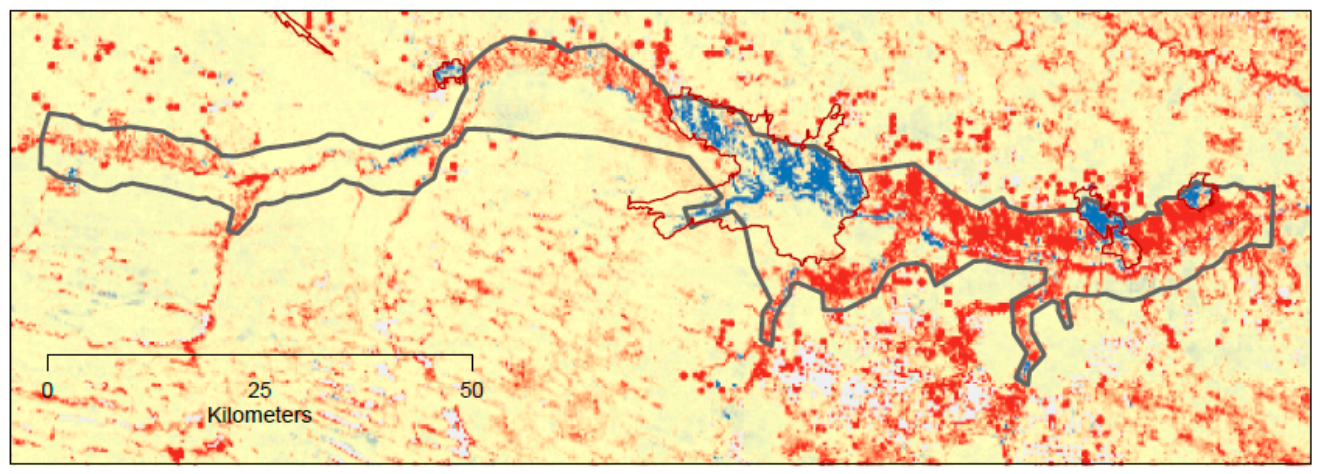

(c)

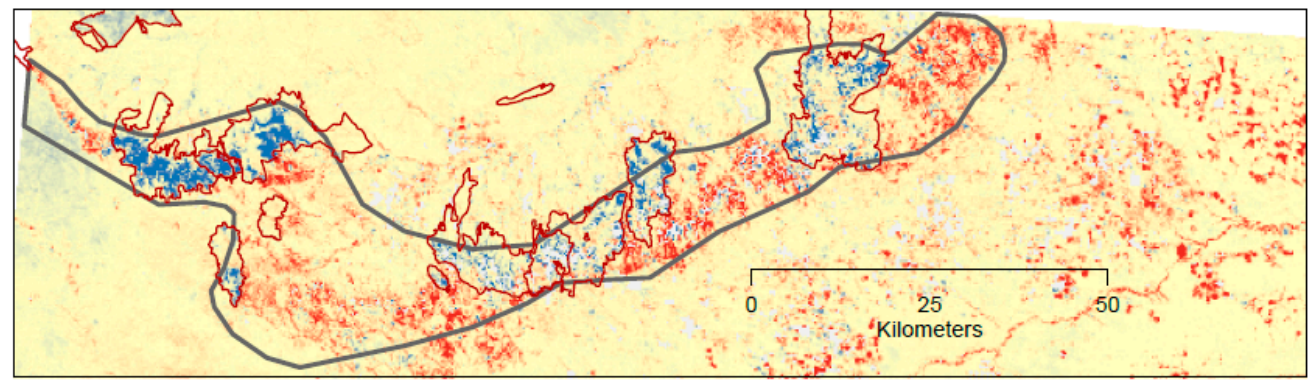

Figure 4. Percent woody cover change from 2000 to 2017 for the Loess Canyons (a), Middle Niobrara (b), and Pine Ridge (c) Biologically Unique Landscapes (BULs), Nebraska, USA. Inset map depicts the location of these BULs in Nebraska. Red polygons show large wildfire perimeters from 2000-2017 (Monitoring Trends in Burn Severity). Black polygons show prescribed burn perimeters in the Loess Canyons from 2000-2017 [54]. Grey areas represent non-rangeland pixels based on Reeves and Mitchell's 2011 classification of US rangelands [43].

The Loess Canyons provides the only example of where management appeared to stabilize a grassland landscape undergoing a transition to woody plant dominance and offers unique insight on how conservation investments can support large-scale ecosystem management in working lands. Conservation investments support landowner-led prescribed burn associations in the Loess Canyons (described in [5]). Prescribed burn associations in this region consist of landowner coalitions, where members pool resources and coordinate the management of Eastern redcedar encroachment across a network of private and public lands. Prescribed burners in the Loess Canyons have adopted the use of high-intensity prescribed fire which allows them to simultaneously control incipient stages of 
encroachment as well as collapse dense infestations of mature Eastern redcedar. To accomplish this, tree clearing programs are often used to cut isolated Eastern redcedar and place them beneath the canopies of larger Eastern redcedar stands, therefore manipulating the fuel structure and generating prescribed fire intensities that surpass juniper mortality thresholds [52,55]. These actions have increased the impact of individual treatments and coordination of large treatments across multiple properties appears to have scaled-up management to match the rate of woody encroachment. Interest in the use of prescribed fire is growing rapidly and further research on conservation partnerships and the collective actions of landowners in the Loess Canyons could hold promising clues on how to better scale-up conservation in other regions and move towards landscape restoration.

No examples in this study point to traditional brush management (i.e., prioritization of mechanical woody plant removal) as a model for sustaining grasslands at large scales and our findings challenge the long-held brush management paradigm of rangelands [42]. The expense of implementing mechanical removal often limits treatments to small-scales when large-scale grassland systems are being lost to woody plant encroachment $[18,19,21]$. This counters the actual rationale and goals behind brush management practices. Brush management is implemented with the goal of removing woody plants to halt or reverse earlier trends of encroachment and restoring desired ecosystem services [11,56]. These goals require woody plant removal to match or outpace the rate of encroachment at targeted scales. However, when woody plant encroachment outpaces control, prioritization of brush management over more proactive management sacrifices more intact grasslands for local grassland restoration projects. Our results indicate that brush management has not kept pace with woody plant encroachment in priority areas and suggests that prioritization of restoration has led to an increasing need for restoration. From 2004 to 2013, the Natural Resource Conservation Service allocated \$7,948,116 towards mechanical tree removal in Nebraska [41], yet, despite these investments woody cover increased in Nebraska over this time period (this study). This illustrates a need to rethink best management practices, implement more diverse strategies with realistic outcome potential, and prioritize practices that reduce the vulnerability of intact grasslands to woody plant transitions.

A move towards more proactive strategies could prove to be beneficial in Nebraska and elsewhere in the Great Plains where more grasslands are vulnerable to woody plant encroachment than can be regained through restoration [26]. With technological advancements in rangeland monitoring [29,54,57], it is now possible to detect early signals of woody plant encroachment at large scales $[20,26,58]$ and spatially target early intervention treatments. Our results show that opportunities exist for more proactive management across all BULs. Even BULs with moderate levels of encroachment still contain intact grassland areas that support at-risk species [27]. These intact grasslands represent cost-effective areas to anchor conservation efforts, reduce their vulnerability to woody encroachment, and work towards landscape-scale stabilization of woody plant encroachment. Such efforts are already underway in Verdigris-Bazile BUL where proactive management has become a top priority. At a statewide scale, our results show early signs of woody encroachment in BULs with low, but increasing woody cover, many of which did not have strategies in place for woody plant control. These BULs provide the most cost-effective opportunities to conserve grasslands at large scales. More detailed assessments of these areas can be used to locate the emergence of woody plant encroachment and identify where management can be targeted to stabilize grassland resources [21]. Moreover, proactive approaches are more likely to align with biodiversity conservation in grassland ecosystems. Grassland species are highly sensitive to habitat fragmentation by woody plants $[59,60]$ and our results indicate substantial rates of habitat loss and fragmentation for grassland-dependent species. For instance, Lesser Prairie Chickens (Tympanuchus pallidicinctus) are 40 times less likely to use grasslands with 5 trees per hectare compared to treeless hectares [61]. Early intervention strategies to counteract woody plant encroachment are therefore prudent for both threat reduction and supporting imperiled grassland species. 


\section{Conclusions}

Delivery of large-scale conservation goals in light of woody plant encroachment will require transitioning from a position of perpetual rehabilitation into a position where the most urgent and important investments are prioritized to conserve grasslands. Our findings identify significant opportunities to build success, learn from past efforts, and adopt more proactive conservation approaches. A key implication is that conservation programs need to consider to how to defend grasslands from woody plant encroachment and prevent small increases in woody cover from resulting in large losses in grassland over time that are extraordinarily difficult and expensive to reverse. This study illustrates how advances in rangeland monitoring can be used to more rapidly execute large-scale adaptive management; still, management implementation across networks of private lands remains a key challenge. Science co-production serves as a model to better couple conservation planning with implementation through science-management partnerships and has made substantial progress in working lands conservation [30,62]. In the Loess Canyons, management-science partnerships have led to collective actions on private lands that halted trends of woody plant encroachment. This example of a community-led approach to managing woody plant encroachment provides a model for improving the performance of conservation investments in working lands. Further research on how to support and foster management-science partnership in working lands will be increasingly important to advancing grassland conservation.

Supplementary Materials: The following are available online at http://www.mdpi.com/2071-1050/12/20/8321/s1. Comparison of woody cover changes between rangelands and afforested rangelands; generalized additive model outputs.

Author Contributions: Conceptualization, D.T.F, C.P.R, D.R.U., V.M.D. and D.T.; Methodology, D.T.F, C.P.R, D.R.U., V.M.D. and D.T.; Formal Analysis, D.T.F, C.P.R, D.R.U. and V.M.D.; Investigation, D.T.F, C.P.R, D.R.U. and V.M.D.; Resources, D.R.U; Writing-Original Draft Preparation, D.T.F, C.P.R, D.R.U., V.M.D. and D.T;; Writing-Review \& Editing, D.T.F, C.P.R, D.R.U., V.M.D., C.R.A, D.E.N., M.O.J., B.W.A. and D.T.; Visualization, D.T.F. and C.P.R; Supervision, D.T.; Funding Acquisition, C.R.A. and D.T. All authors have read and agreed to the published version of the manuscript.

Funding: Funding for this research was provided by Nebraska Game \& Parks Commission (W-125-R-1), the National Science Foundation (OIA-1920938), the University of Nebraska's Institute of Agriculture and Natural Resources, Department of Defense Strategic Environmental Research and Development Program (W912HQ-15-C-0018), and the Arthur W. Sampson Fellowship Fund (University of Nebraska-Lincoln).

Acknowledgments: The Nebraska Cooperative Fish and Wildlife Research Unit is jointly supported by a cooperative agreement between the United States Geological Survey, the Nebraska Game and Parks Commission, the University of Nebraska-Lincoln, the United States Fish and Wildlife Service, and the Wildlife Management Institute.

Conflicts of Interest: The authors declare no conflict of interest.

\section{References}

1. Anadon, J.D.; Sala, O.E.; Turner, B.L., II; Bennett, E.M. Effect of woody-plant encroachment on livestock production in North and South America. Proc. Natl. Acad. Sci. USA 2014, 111, 12948-12953. [CrossRef]

2. Jackson, R.B.; Jobbágy, E.G.; Avissar, R.; Roy, S.B.; Barrett, D.J.; Cook, C.W.; Farley, K.A.; le Maitre, D.C.; McCarl, B.A.; Murray, B.C. Trading water for carbon with biological carbon sequestration. Science 2005, 310, 1944-1947. [CrossRef]

3. Ratajczak, Z.; Nippert, J.B.; Collins, S.L. Woody encroachment decreases diversity across North American grasslands and savannas. Ecology 2012, 93, 697-703. [CrossRef] [PubMed]

4. Nackley, L.L.; West, A.G.; Skowno, A.L.; Bond, W.J. The nebulous ecology of native invasions. Trends Ecol. Evol. 2017, 32, 814-824. [CrossRef]

5. Twidwell, D.; Rogers, W.E.; Fuhlendorf, S.D.; Wonkka, C.L.; Engle, D.M.; Weir, J.R.; Kreuter, U.P.; Taylor, C.A., Jr. The rising Great Plains fire campaign: citizens' response to woody plant encroachment. Front. Ecol. Environ. 2013, 11, e64-e71. [CrossRef] 
6. Archer, S.R.; Andersen, E.M.; Predick, K.I.; Schwinning, S.; Steidl, R.J.; Woods, S.R. Woody Plant Encroachment: Causes and Consequences. In Rangeland Systems: Processes, Management and Challenges; Springer Series on Environmental Management; Briske, D.D., Ed.; Springer International Publishing: Cham, Switzerland, 2017; pp. 25-84. ISBN 978-3-319-46709-2.

7. Bond, W.J. What limits trees in C4 grasslands and savannas? Annu. Rev. Ecol. Evol. Syst. 2008, 39, 641-659. [CrossRef]

8. Van Auken, O.W. Causes and consequences of woody plant encroachment into western North American grasslands. J. Environ. Manag. 2009, 90, 2931-2942. [CrossRef] [PubMed]

9. Rosenberg, K.V.; Dokter, A.M.; Blancher, P.J.; Sauer, J.R.; Smith, A.C.; Smith, P.A.; Stanton, J.C.; Panjabi, A.; Helft, L.; Parr, M.; et al. Decline of the North American avifauna. Science 2019, 366, 120-124. [CrossRef] [PubMed]

10. Van Wilgen, B.W.; Forsyth, G.G.; Le Maitre, D.C.; Wannenburgh, A.; Kotzé, J.D.F.; van den Berg, E.; Henderson, L. An assessment of the effectiveness of a large, national-scale invasive alien plant control strategy in South Africa. Biol. Conserv. 2012, 148, 28-38. [CrossRef]

11. Archer, S.R.; Davies, K.W.; Fulbright, T.E.; Mcdaniel, K.C.; Wilcox, B.P.; Predick, K.I. Brush management as a rangeland conservation strategy: A critical evaluation. In Conservation Benefits of Rangeland Practices: Assessment, Recommendations, and Knowledge Gaps; Briske, D.D., Ed.; Natural Resources Conservation Service: Washington, DC, USA, 2011; pp. 105-170. ISBN 978-0-9849499-0-8.

12. Parr, C.L.; Lehmann, C.E.R.; Bond, W.J.; Hoffmann, W.A.; Andersen, A.N. Tropical grassy biomes: Misunderstood, neglected, and under threat. Trends Ecol. Evol. 2014, 29, 205-213. [CrossRef]

13. Zou, C.; Twidwell, D.; Bielski, C.; Fogarty, D.; Mittelstet, A.; Starks, P.; Will, R.; Zhong, Y.; Acharya, B.; Zou, C.B.; et al. Impact of Eastern redcedar proliferation on water resources in the Great Plains USA—Current state of knowledge. Water 2018, 10, 1768. [CrossRef]

14. De Wit, M.P.; Crookes, D.J.; van Wilgen, B.W. Conflicts of interest in environmental management: Estimating the costs and benefits of a tree invasion. Biol. Invasions 2001, 3, 167-178. [CrossRef]

15. Donovan, V.M.; Wonkka, C.L.; Wedin, D.A.; Twidwell, D. Land-use type as a driver of large wildfire occurrence in the U.S. Great Plains. Remote Sens. 2020, 12, 1869. [CrossRef]

16. Swallow, B.; Mwangi, E. Prosopis juliflora invasion and rural livelihoods in the Lake Baringo Area of Kenya. Conserv. Soc. 2008, 6, 130. [CrossRef]

17. Marais, C.; Van Wilgen, B.W.; Stevens, D. The clearing of invasive alien plants in South Africa: A preliminary assessment of costs and progress. South Afr. J. Sci. 2004, 100, 97-103.

18. Tanaka, J.A.; Brunson, M.; Torell, L.A. A social and economic assessment of rangeland conservation practices. In Conservation Benefits of Rangeland Practices: Assessment, Recommendations, and Knowledge Gaps; Briske, D.D., Ed.; Natural Resources Conservation Service: Washington, DC, USA, 2011; pp. 371-422.

19. Twidwell, D.; Allred, B.W.; Fuhlendorf, S.D. National-scale assessment of ecological content in the world's largest land management framework. Ecosphere 2013, 4, art94. [CrossRef]

20. Filippelli, S.K.; Vogeler, J.C.; Falkowski, M.J.; Meneguzzo, D.M. Monitoring conifer cover: Leaf-off lidar and image-based tracking of eastern redcedar encroachment in central Nebraska. Remote Sens. Environ. 2020, 248, 111961. [CrossRef]

21. Jones, M.O.; Naugle, D.E.; Twidwell, D.; Uden, D.R.; Maestas, J.D.; Allred, B.W. Beyond inventories: Emergence of a new era in rangeland monitoring. Rangel. Ecol. Manag. 2020. [CrossRef]

22. Stevens, N.; Lehmann, C.E.R.; Murphy, B.P.; Durigan, G. Savanna woody encroachment is widespread across three continents. Glob. Change Biol. 2017, 23, 235-244. [CrossRef]

23. Wang, J.; Xiao, X.; Qin, Y.; Doughty, R.B.; Dong, J.; Zou, Z. Characterizing the encroachment of juniper forests into sub-humid and semi-arid prairies from 1984 to 2010 using PALSAR and Landsat data. Remote Sens. Environ. 2018, 205, 166-179. [CrossRef]

24. McConnachie, M.M.; Cowling, R.M.; van Wilgen, B.W.; McConnachie, D.A. Evaluating the cost-effectiveness of invasive alien plant clearing: A case study from South Africa. Biol. Conserv. 2012, 155, 128-135. [CrossRef]

25. Roberts, C.P.; Uden, D.R.; Allen, C.R.; Twidwell, D. Doublethink and scale mismatch polarize policies for an invasive tree. PLOS ONE 2018, 13, e0189733. [CrossRef] [PubMed]

26. Falkowski, M.J.; Evans, J.S.; Naugle, D.E.; Hagen, C.A.; Carleton, S.A.; Maestas, J.D.; Khalyani, A.H.; Poznanovic, A.J.; Lawrence, A.J. Mapping tree canopy cover in support of proactive prairie grouse conservation in western North America. Rangel. Ecol. Manag. 2017, 70, 15-24. [CrossRef] 
27. Schneider, R.K.; Stoner, K.; Steinauer, G.; Panella, M.; Humbert, M. (Eds.) The Nebraska Natural Legacy Project: State Wildife Action Plan, 2nd ed.; Nebraska Game and Parks Commission: Lincoln, NE, USA, 2011; p. 344.

28. Van Pelt, W.E.; Kyle, S.; Pitman, J.; Klute, D.; Beauprez, G.; Schoeling, D.; Janus, A.; Haufler, J. The Lesser Prairie-Chicken Range-Wide Conservation Plan; Western Association of Fish and Wildlife Agencies: Cheyenne, WY, USA, 2013; p. 55.

29. Jones, M.O.; Allred, B.W.; Naugle, D.E.; Maestas, J.D.; Donnelly, P.; Metz, L.J.; Karl, J.; Smith, R.; Bestelmeyer, B.; Boyd, C.; et al. Innovation in rangeland monitoring: Annual, $30 \mathrm{~m}$, plant functional type percent cover maps for U.S. rangelands, 1984-2017. Ecosphere 2018, 9, e02430. [CrossRef]

30. Reinhardt, J.R.; Filippelli, S.; Falkowski, M.; Allred, B.; Maestas, J.D.; Carlson, J.C.; Naugle, D.E. Quantifying pinyon-juniper reduction within North America's sagebrush ecosystem. Rangel. Ecol. Manag. 2020, 73, 420-432. [CrossRef]

31. Carr, S.L.; Riley, S.P.; Stoner, K.; Steinauer, G.; Walker, T.L. Influence of the federal landowner Incentive Program. Wildl. Soc. Bull. 2019, 43, 355-362. [CrossRef]

32. Engle, D.M.; Coppedge, B.R.; Fuhlendorf, S.D. From the dust bowl to the green glacier: Human activity and environmental change in Great Plains grasslands. In Western North American Juniperus Communities: A Dynamic Vegetation Type; Van Auken, O.W., Ed.; Springer: New York, NY, USA, 2008; pp. 253-271. ISBN 978-0-387-34003-6.

33. Chapman, S.S.; Omernik, J.; Freeouf, J.; Huggins, D.; McCauley, J.; Freeman, C.; Steinauer, G.; Angelo, R.; Schlepp, R. Ecoregions of Nebraska and Kansas; U.S. Geological Survey: Reston, VA, USA, 2001.

34. Epstein, H.E.; Lauenroth, W.K.; Burke, I.C.; Coffin, D.P. Regional productivities of plant species in the Great Plains of the United States. Plant Ecol. 1998, 134, 173-195. [CrossRef]

35. High Plains Regional Climate Center. Available online: https://hprcc.unl.edu/ (accessed on 2 October 2020).

36. Wells, P. Postglacial vegetational history of the Great Plains. Science 1970, 167, 1574-1582. [CrossRef]

37. Axelrod, D.I. Rise of the grassland biome, central North America. Bot. Rev. 1985, 51, 163-201. [CrossRef]

38. Donovan, V.M.; Burnett, J.L.; Bielski, C.H.; Birgé, H.E.; Bevans, R.; Twidwell, D.; Allen, C.R. Social-ecological landscape patterns predict woody encroachment from native tree plantings in a temperate grassland. Ecol. Evol. 2018, 8, 9624-9632. [CrossRef]

39. Ganguli, A.C.; Engle, D.M.; Mayer, P.M.; Fuhlendorf, S.D. When are native species inappropriate for conservation plantings? Rangelands 2008, 30, 27-32. [CrossRef]

40. Briggs, J.M.; Blair, J.M.; Mccarron, J. An ecosystem in transition: Causes and consequences of the conversion of mesic grassland to shrubland. BioScience 2005, 55, 561-572. [CrossRef]

41. Simonsen, V.; Fleischmann, J.; Whisenhunt, D.; Volesky, J.; Twidwel, D. Act Now or Pay Later: Evaluating the Cost of Reactive versus Proactive Eastern Redcedar Management; University of Nebraska-Lincoln Extension; EC1784; Institute of Agriculture and Natural Resources: Lincoln, NE, USA, 2015.

42. Garmestani, A.; Twidwell, D.; Angeler, D.G.; Sundstrom, S.; Barichievy, C.; Chaffin, B.C.; Eason, T.; Graham, N.; Granholm, D.; Gunderson, L.; et al. Panarchy: Opportunities and challenges for ecosystem management. Front. Ecol. Environ. 2020. [CrossRef]

43. Reeves, M.C.; Mitchell, J.E. Extent of coterminous US rangelands: Quantifying implications of differing agency perspectives. Rangel. Ecol. Manag. 2011, 64, 585-597. [CrossRef]

44. Wood, S. Fast stable restricted maximum likelihood and marginal likelihood estimation of semiparametric generalized linear models. J. R. Stat. Soc. Series. B. Stat. Methodol. 2011, 73, 3-36. [CrossRef]

45. Mann, H.B. Nonparametric tests against trend. Econometrica 1945, 13, 245. [CrossRef]

46. Yue, S.; Pilon, P.; Cavadias, G. Power of the Mann-Kendall and Spearman's rho tests for detecting monotonic trends in hydrological series. J. Hydrol. 2002, 259, 254-271. [CrossRef]

47. R Core Team. R: A Language and Environment for Statistical Computing; R Foundation for Statistical Computing: Vienna, Austria, 2018; Available online: https://www.r-project.org (accessed on 2 October 2020).

48. Yokomizo, H.; Possingham, H.P.; Thomas, M.B.; Yvonne, M.; Yokomizo, H.; Possingham, H.P.; Thomas, M.B.; Buckley, Y.M. Managing the impact of invasive species: The value of knowing the density-impact curve. Ecol. Appl. 2016, 19, 376-386. [CrossRef]

49. Donovan, V.M.; Twidwell, D.; Uden, D.R.; Tadesse, T.; Wardlow, B.D.; Bielski, C.H.; Jones, M.O.; Allred, B.W.; Naugle, D.E.; Allen, C.R. Resilience to large, "catastrophic" wildfires in North America's grassland biome. Earth's Future 2020, 8, e2020EF001487. [CrossRef] 
50. Twidwell, D.; Bielski, C.H.; Scholtz, R.; Fuhlendorf, S.D. Advancing fire ecology in 21st century rangelands. Rangel. Ecol. Manag. 2020. [CrossRef]

51. Smit, I.P.J.; Asner, G.P.; Govender, N.; Vaughn, N.R.; van Wilgen, B.W. An examination of the potential efficacy of high-intensity fires for reversing woody encroachment in savannas. J. Appl. Ecol. 2016, 53, 1623-1633. [CrossRef]

52. Twidwell, D.; Rogers, W.E.; Wonkka, C.L.; Taylor, C.A.; Kreuter, U.P. Extreme prescribed fire during drought reduces survival and density of woody resprouters. J. Appl. Ecol. 2016, 53, 1585-1596. [CrossRef]

53. Roberts, C.P.; Donovan, V.M.; Wonkka, C.L.; Powell, L.A.; Allen, C.R.; Angeler, D.G.; Wedin, D.A.; Twidwell, D. Fire legacies in eastern ponderosa pine forests. Ecol. Evol. 2019, 9, 1869-1879. [CrossRef] [PubMed]

54. Uden, D.R.; Twidwell, D.; Allen, C.R.; Jones, M.O.; Naugle, D.E.; Maestas, J.D.; Allred, B.W. Spatial imaging and screening for regime shifts. Front. Ecol. Evol. 2019, 7, 407. [CrossRef]

55. Twidwell, D.; Fuhlendorf, S.D.; Taylor, C.A.; Rogers, W.E. Refining thresholds in coupled fire-vegetation models to improve management of encroaching woody plants in grasslands. J. Appl. Ecol. 2013, 50, 603-613. [CrossRef]

56. US Department of Agriculture. Natural Resources Conservation Service Conservation Practice Standard: Brush Management; USDA: Washington, DC, USA, 2017; pp. 1-5.

57. Robinson, N.P.; Allred, B.W.; Smith, W.K.; Jones, M.O.; Moreno, A.; Erickson, T.A.; Naugle, D.E.; Running, S.W. Terrestrial primary production for the conterminous United States derived from Landsat $30 \mathrm{~m}$ and MODIS 250 m. Remote Sens. Ecol. Conserv. 2018, 4, 264-280. [CrossRef]

58. Roberts, C.P.; Twidwell, D.; Burnett, J.L.; Donovan, V.M.; Wonkka, C.L.; Bielski, C.L.; Garmestani, A.S.; Angeler, D.G.; Eason, T.; Allred, B.W.; et al. Early warnings for state transitions. Rangel. Ecol. Manag. 2018, 71, 659-670. [CrossRef]

59. Cunningham, M.A.; Johnson, D.H. Narrowness of habitat selection in woodland and grassland birds. Avian Conserv. Ecol. 2019, 14, 14. [CrossRef]

60. Fuhlendorf, S.D.; Woodward, A.J.W.; Leslie, D.M.; Shackford, J.S. Multi-scale effects of habitat loss and fragmentation on lesser prairie-chicken populations of the US Southern Great Plains. Landsc. Ecol 2002, 17, 617-628. [CrossRef]

61. Lautenbach, J.M.; Plumb, R.T.; Robinson, S.G.; Hagen, C.A.; Haukos, D.A.; Pitman, J.C. Lesser prairie-chicken avoidance of trees in a grassland landscape. Rangel. Ecol. Manag. 2017, 70, 78-86. [CrossRef]

62. Naugle, D.E.; Allred, B.W.; Jones, M.O.; Twidwell, D.; Maestas, J.D. Coproducing science to inform working lands: The next frontier in nature conservation. BioScience 2020, 70, 90-96. [CrossRef] [PubMed] 